\title{
TRANSNATIONAL INITIATIVES TOWARDS NATURAL RESOURCE GOVERNANCE IN AFRICA POST-2015
}

\author{
Timothy M. Shaw*
}

Over the next five years ... the average African economy will outpace its Asian counterpart ... Africa's economy will grow at an average annual rate of $7 \%$ over the next 20 years, slightly faster than China's ... Africa's changing fortunes have largely been driven by China's surging demand...but other factors have also counted. ... Without reforms, Africa will not be able to sustain faster growth. But its lion economies are earning a place alongside Asia's tigers. - The Economist, 2011: $73^{1}$

\begin{abstract}
The 21st century is marked by a welcome proliferation of innovative forms of natural resource governance to advance sustainable development. This article sheds light on the background for this quite remarkable and unanticipated shift. It analyses the prospects for AMV advocacy and adoption by emerging state and non-state actors by the end of this decade, both in Africa and beyond. It examines these evolving perspectives and debates vis á vis 21 st century globalization. It also identifies the unexpected and unprecedented range of transnational governance initiatives that have been proposed since the turn of the century. These continue to proliferate and compete, being refined in the process as the problematic notion of global governance continues to be a subject of considerable debate. It also extends the range of developmental challenges to include the burgeoning water-energy-food nexus.
\end{abstract}

Keywords: governance, Africa, economy, development

DOI: https://dx.doi.org/10.4314/jsdlp.v8i1.9

* PhD, Princeton, is visiting professor at University of Massachusetts, Boston and Adjunct Professor at Aalborg, Carleton University, and University of Ottawa. With degrees from three continents - University of Sussex, Makerere University and Princeton University - he has held visiting positions in China, Japan, Nigeria, South Africa, United Kingdom, Zambia and Zimbabwe as well as in Canada and the US. He continues to edit IPE Series for Palgrave Macmillan/Springer and Routledge.

1 The Economist, "Special Report, Emerging Africa: A Hopeful Continent" (2013) Vol. 406 (8825), pp. 1-16. 


\section{INTRODUCTION}

The second decade of the 21st century may be that of Africa's renaissance, despite the financial crisis of 2014 to 2016, extended and exacerbated by the Brexit vote of mid-2016. Post-2015, in particular, Africa remains the secondfastest growing continent after Asia. Symbolic of earlier times, The Economist (2013) had labelled the continent "hopeless"yet in March 2013 it published a special report on "Emerging Africa: A Hopeful Continent".

At the start of 2016, Rick Rowden renewed his contradiction on the notion of Africa rising, echoing the scepticism of Ian Taylor. ${ }^{2}$ Yet Robertson and Moran still maintain that Africa has agency because of growth in India rather than China and because of its post-industrial development direction; ${ }^{3}$ and Tom Bundervoet remains hopeful. Notably, growth will not translate into sustainable development unless Natural Resource Governance (NRG) is improved both on and around the continent. ${ }^{4}$

Africa's economic agencies- UNECA along with the AfDB, AU, and UNDP - have come to advocate the adoption of policies leading towardsdevelopmental states. ${ }^{5}$ This comes one decade after Thandika Mkandawire (2001) first put the concept on the agenda.In response to a decade of commodity boom, the continent has now articulated an Africa Mining Vision (AMV 2009, 2011a and b). This contrasts with other possible strategies for such governance from assorted global developmental, environmental, financial and industrial agencies; these vary from intraregional, interregional, and unisectoral approaches to multisectoral solutions (see sections II and III below). ${ }^{6}$

This articleexaminesthese evolving perspectives and debates vis-ávis 21 st century globalization. Itidentifies the unexpected and unprecedented range of transnational governance initiatives that have

2 Taylor Ian C., "Africa Rising? BRICS-diversifying dependency" (Woodbridge, Suffolk: James Currey 2014).

3 Moran Michael, "Private Foundations \& Development Partnerships: American Philanthropy and Global Development" (Abingdon: Routledge 2014).

4 Bilal San et al (eds), "Thematic Focus: From Growth to Transformation: What Role for the Extractive Sector" (ECDPM GREAT Insights 2013), Vol. 2(2), 1-32.

5 Singh, J. N. and France, B. (eds.), "Resource Governance and Developmental States in the Global South: Critical international political economy perspectives", (London: Palgrave Macmillan 2013).

6 Florini, A. and Navroz, K. D., "Special Issue: Global Energy Governance", Global Policy 2 (2011)1-154. 
been proposed since the turn of the century. ${ }^{7}$ These continue to proliferate and compete, being refined in the process as the problematic notion of global governance continues to be a subject of considerable debate. It alsoextends the range of developmental challenges to include the burgeoning water-energy-food nexus.

This articlesheds light on the background for this quite remarkable and unanticipated shift.It analyses the prospects for AMV advocacy and adoption by emerging state and non-state actors by the end of this decade, both in Africa and beyond. In so doing, enlightened by Lucy Corkin's (2013) analysis of Angola's leverage over China's Export Import Bank (EXIM Bank), I invoke the emerging "agency" versus "dependency" debate as a correlate of the continent's recent unprecedented growth. ${ }^{8}$ This sets Africa apart from the recent economic difficulties and setbacks witnessed in many of the member states of theOrganization for Economic Cooperation and Development (OECD), especially the Eurozone. This corresponds with the theme of the UNDP's 2013 Human Development Report (HDR) on the rise of the South, whileadvancing a comparative analysis of heterogeneous governance initiatives originating in Africa (e.g. www.africaprogresspanel.org)and elsewhere.

Moreover, this essay juxtaposes two dominant, interrelated strands in the political economy of the continent today: the impact of the BRICS, and the prospect of another commodities boom.I address these encouraging developments in contradistinction with the difficulties being encountered by the Eurozone's PIIGS countries - alongside the declining salience of the EU - which is perhaps best symbolized by the

7 Brown Stuart (eds.), "Transnational Transfers and Global Development" (London: Palgrave Macmillan 2011). See also Cornelissen Scarlett, "Corporate Social Responsibility as a Social Development Paradigm in Africa's Political Economy: Its Emergence and Implications for African Agency" in Brown and Harman (eds), "African Agency in International Politics" (2013), 114-126; Dingwerth Klaus, "Private Transnational Governance and the Developing World", International Studies Quarterly (2008), Vol. 52(3), 607-634; KhagramSanjeev, "Dams and Development: Transnational Strategies For Water and Power" (Ithaca: Cornell University Press 2004).

8 Brown William, "A Question of Agency: Africa in International Politics" Third World Quarterly (2012) Vol. 33(10), 1889-1908. See also Harman, S. and William, B. "In from the Margins? The Changing Place of African International Relations", International Affairs (2013) Vol. 89(1) 69-87; and Lorenz, U. and Martin, R. (eds), "Comparing Regionalisms in Africa: Mapping Agency" (Farnham: Ashgate 2013). 
decade-long stalling of its Economic Partnership Agreements (EPAs) with East andWest Africa.

It also underscores the importance of African NRG avoiding the resource curse, as well as the need for African countries to adopt a Botswana-inspired, democratic developmental state model for such administration (Mbabazi and Taylor 2005, Mkandawire 2001, UNDP 2013).The catalytic role a new generation of African policy advocates is key and determines how to capably seize uponwhat could be a fleeting opportunity to effectively administer and grow Africa's extractives sector. This has become imperative ${ }^{9}$ given the transition from MDGs to SDGs and the higher responsibilities that go with the change. ${ }^{10}$

Sovereign Wealth Funds (SWFs), Faith-Based Organizations (FBOs), and other new donors and foundations constitute novel sources of finance that often engage in global public partnerships that may facilitate sustainable African NRG. The continent's increasing salience was illuminated by a set of articles that appeared in International Affairs from Chatham House at the start of 2013; including a review of the field by Sophie Harman and William Brown (2013), which focused on two contrasting case studies on China in Africa, and HIV/AIDS: topics emblematic of how Africa seems to be perceived in the popular imagination overseas.

Half of the dozen fastest growing countries identified in The Economist's "World in 2011"were African as were four in 2016. ${ }^{11}$ Such growth andits associated changes to the nature of governance in Africa may expand the possibility and reach of agency of African countries and communities. ${ }^{12}$ This may have a positive, knock-on effect on the ability of a range of African state and non-state actors to impact decisions and directions at a variety of levels by expanding their room for manoeuvre. ${ }^{13}$

This unanticipated possibility is not just a function of continuing growth courtesy of the BRICS, especially China. ${ }^{14}$ It also results from

9 ibid Bilal, 2013.

10 Kararach, Besada \& Shaw, 2015.

11 The Economist, “The Lion Kings?” (2011) Vol. 398 (8715), 72-73.

12 Brown, 2012; Brown and Harman, 2013; Lorenz and Rempe, 2013.

13 Africa Progress Panel, Report (Geneva, 2012).

14 Xing, Li (eds), China-Africa Relations: The Past, the Present and the Future (Farnham: Ashgate, 2013). 
global rebalancing as the initial trans-Atlantic crisis at the end of the first decade spills over into the PIIGS of the eurozone ${ }^{15}$ with Official Development Assistance (ODA) from the OECD countries declining significantly. ${ }^{16}$ Development of Africa's extractives sector and its promisingly beneficial effect was evidenced in the 2012 edition Unleashing Africa's Potential as a Pole of Global Growthand parallel reports from UNDP (2012b); the first Human Development Report (HDR for the continent. ${ }^{17}$

The AfDB and OECDhave adopted similar positions. Such prognostications build on an early collection on Botswana and Uganda ${ }^{18}$ based on the original Mkandawire formulation. ${ }^{19}$ Given historic weaknesses along with recent debilitating conditionalities, the African developmental state requires robust partnerships to function effectively. ${ }^{20}$ These, in turn, limit any authoritarian tendencies and impose a degree of accountability that is both external and internal.

A number of innovative volumes suggest that agency surrounding regional development in sub-Saharan Africa constitutes a dramatic divergence from established dependency assumptions and perspectives. ${ }^{21}$ That is to say, these works are novel because they view African economies as policy-makers rather than policy-takers.

15 Overbeek, H. and Bastiaan, van A (eds.), Neoliberalism in Crisis (London: Palgrave Macmillan, 2012).

16 Sumner, A. and Richard M., The Future of Foreign Aid: Development Cooperation and The New Geography of Global Poverty (London: Palgrave Macmillan 2013); also see Vom H. Matthias, James S. and David, H., "Beyond the BRICs: Alternative Strategies of Influence in the Global Politics of Development" European Journal of Development Research (2012) Vol. 24(2) 187-204 <www.oecd.org>

17 UNECA, Economic Report on Africa 2012: Unleashing Africa's Potential As a Pole of Global Growth (Addis Ababa, 2012).

18 Mbabazi, P. and Ian, T. (eds), "The Potentiality of 'Developmental States' in Africa" (Dakar: CODESRIA, 2005).

19 Mkandawire Thandika, "Thinking about Developmental States in Africa" Cambridge Journal of Economics (2001), Vol. 25(3): 289-313.

20 UNDP, "Human Development Report 2013: The Rise of the South: Human Progress in a Diverse World (New York, 2013).

21 Corkin, Lucy, "Uncovering African Agency: Angola's Management of China's credit lines". Also see Hanson, K. T., George, K. and Timothy, M. S. (eds), "Rethinking Development Challenges for Public Policy: Insights From Contemporary Africa" (London: Palgrave Macmillan 2012); and Shaw Timothy M, “Africa's Quest for Developmental States: 'Renaissance' for Whom?” Third World Quarterly (2012), Vol. 33(5) 837-851 (Farnham: Ashgate, 2013). 


\section{VARIETIES OF AFRICAN AGENCY}

This analysis focuses on five major developments in agency, especially at the regional level.These suggest, above all, that the character of development is very much in flux in Africa. First, with particular relevance for this analysis, African stakeholders have been central to a set of innovations in transnational governance, including CSR, contributing to the Kimberley Process (KP) at the end of the 20th centuryand to the Extractive Industries Transparency Initiative (EITI) at the turn of the 21st, also participating in Dodd-Frank deliberations in the US within the last decade. ${ }^{22}$

Second, African regions have generated a series of innovations in transnational governance, from the Maputo Corridor to trans-frontier peace parks and the Tripartite Free Trade Agreement (T-FTA) between the Southern African Development Community (SADC), East African Community (EAC), and Common Market for Eastern and Southern Africa (COMESA) ${ }^{23}$ African participation in such novel approaches to governance has laid the intellectual and institutional seedbed for further domestic policy making leadership in the development of the continent's extractives sectors, and the growth of sub-Saharan African economies.

A third major development in agencywas South Africa'srecognition as the fifth member of the BRICS. This raises questions about the biggest economy on the continent, and its leadership aspirations at the regional, continental and global levels. ${ }^{24}$ Fourth, if we expand our purview from the continent itself to its diasporas concentrated in Europe and North America, agency through remittances is likely to become even more influential in the years ahead. ${ }^{25}$ Fifth and finally, there are novel forms of African agency being undertaken through a revived and reoriented

22 Cornelissen, Scarlett, Fantu C. and Timothy, M. S. (eds), Africa and International Relations in the Twenty-first Century (London: Palgrave Macmillan 2011) and (updated pb edition 2015).

23 Hansohm Dirk, "South Sudan, Sudan \& the East African Community: Potential of Enhanced Relationships" (Bruges: UNU-CRIS. Working Papers W-2013/4). Hartzenberg Trudi et al, "The Tripartite Free Trade Area: Towards A New African Integration Paradigm?" (Stellenbosch: Tralac 2012).

24 Flemes, Daniel (eds.), "Regional Leadership in the Global System: Ideas, Interests and Strategies of Regional Powers" (Farnham: Ashgate 2010). Also see Nel Philip et al (eds), "Special Issue: Regional Powers And Global Redistribution" Global Society (2012), Vol. 26(3): 279-405.

25 Ratha Dilip et al, "Leveraging Remittances for Africa: Remittances, Skills and Investments" (Washington DC: World Bank \& AfDB, 2011). 
AU in de facto regional conflict zones like the Great Lakes, Horn of Africa, Sahel, and other areas with notable energy and minerals sectors. ${ }^{26}$ Taken together, we need to redefine notions of agency to reflect Africa in the new millennium as a burgeoning part of the global South. ${ }^{27}$

In a series of reports from the present decade, the Center for Global Development (CGD) in Washington, DC now suggests that 17 African countries are leading the way, as they have attained steady economic growth and considerably strengthened their democracies, ameliorated their governance institutions, and reduced poverty since the 1990s. ${ }^{28}$ Similarly, McKinsey has lauded the continent's "lion kings", while the Boston Consulting Group (BCG)) has identified 40 African corporations as global "challengers" across several economic sectors, with Togo's upstart Ecobank, now partially owned by Qatar,figuring among them. ${ }^{29}$

The rest of thisarticlehas four interrelated parts, which stake out paths to a brighter future for the continent centred on its regional innovations, including its myriad diasporas. First, we examine the $21 \mathrm{st}$ century's new multilateralisms and transnational governance in the light of African agency. These multilateralisms are dynamic, and span several emerging sectors from the International Campaign to Ban Landmines (ICBL) and Ottawa Process, to the Kimberley Process with Partnership Africa Canada (PAC), Global Witness (GW), Diamond Development Initiative (DDI), and ISEALAlliance. ${ }^{30}$ The continent is

26 Bagayoko Niagale, "Introduction: Hybrid Security Governance in Africa" IDS Bulletin (2012), No. 43(4), accessed 1 July 2013. Also see Besada Hany (eds.), Crafting an African Security Architecture: Addressing Regional Peace and Conflict in the 21st Century (Farnham: Ashgate, 2010); Klare Michael T., The Race for What's Left: The global scramble for the world's last resources (New York: Metropolitan, 2012); Nathan, Laurie, Community of Insecurity: SADC's struggle for peace and security in Southern Africa (Farnham: Ashgate, 2012).

27 UNDP, "African Human Development Report 2012: Towards a Food Secure Future" (New York, 2012b); UNECA, "Economic Report on Africa 2011: Governing Development in Africa - The Role of the State in Economic Transformation" (Addis Ababa, 2011); UNECA, "African Governance Report III 2012: Elections and The Management Of Diversity in Africa" (NY: OUP 2013).

28 Radelet Steven, "Emerging Africa: How 17 Countries Are Leading the Way" (Washington DC: Centre for Global Dialogue, 2010).

29 McKinsey, "McKinsey on Africa: a continent on the move" (New York, 2010). Boston Consulting Group, "The African Challengers: Global Competitors Emerge from the Overlooked Continent" (Boston, 2010).

30 Cadman Timothy, Quality and Legitimacy of Global Governance: Case Lessons from Forestry (London: Palgrave Macmillan, 2011); Gale, Fred and Marcus, H., "Global Commodity Governance: State Responses To Sustainable Forest and Fisheries Certification” (London: Palgrave Macmillan, 2011). 
defining its own AMV; in contrast to the Paul Collier/World Bank Natural Resource Charter (NRC), now part of the NRGI. ${ }^{31}$ At the regional level, theInternational Conference on the Great Lakes Region (ICGLR) nexus - which includes GW and PAC - is a multilateral collaboration that has afforded these institutions greater agency in interpreting and applying the SEC Section 1502 rules.

The second part addresses the post-Washington Consensus (Sumner and Mallett 2013, vom Hau, Scott and Hulme 2012). Given broadly declining ODA from OECD countries in recent years, a range of innovative sources of finance have been identified, including the global solidarity fund, currency transaction tax, carbon taxes/trading, climate change funds, controls on money laundering, and remittance taxes. In addition, emerging donors like the BRICS and Gulf States and newer private entities such as the Bill and Melinda Gates, as well as Clinton and Mo Ibrahim Foundations have given rise to institutions such as the African Green Revolution Forum (AGRA) and Global Alliance for Vaccines and Immunization (GAVI), among other things. ${ }^{32}$

Third, by focusing on a recent collection by new scholars (Lorenz and Rempe 2013), Africa has generated an innovative range of new regionalisms involving a range of non-state actors. These regionalisms include the Nile Basin Initiative (NBI) and Dialogue and continental, corporate supply chains, which were augmented through Dodd-Frank provisions ahead of 2015.

Lastly, this article examinesthe implications that the emergence of new multilateralisms, regionalisms, and sources of finance may have on analyses and policies that are both state and non-state in nature. For instance, we consider the agents, innovators and animators of the AMV by attempting to answer the following question: how is the developmental state in Africa this decade, such as Botswana, different from that in Asia at the end of the 20th century; i.e. beyond the NICs? (Mbabazi and Taylor 2005, Mkandawire, 2001).

Informed by contemporary international relations (Cornelissen, Cheru and Shaw, 2015; Dunn and Shaw, 2013) and developmental

31 Available at <www.resourcegovernance.org > accessed March 2016.

32 Gray, K. and Craig, N. M. (eds.), "Special Issue: Rising Powers and the Future of Global Governance", Third World Quarterly (2013), Vol. 32(2), 183-355 (re-issued in book version by Routledge in 2013); Mawdsley Emma, "From Recipients to Donors: Emerging Powers and the Changing Development Landscape" (London: Zed, 2012). 
studies perspectives in particular, our analysis identifies emerging opportunities and challenges for African agency in the middle of the second decade of the 21st century. It especially focuses on whether the emergence of the BRICS, or second world (Khanna, 2009), presents unanticipated possibilities or threats to a heterogeneous continent; one which includes burgeoning developmental as well as fragile or failed states. ${ }^{33}$

As suggested in the section that follows, this is the welcome challenge or opportunity facing Africa at the start of its second fifty year, post-independence period, symbolized by the AU. This is a point at which Africa can ask itself what it has learned, so that it can adapt after its first half century; given the significantly transformed global context at the turn of the decade in the wake of the global financial crisis, that sawthe global South endure a significantly lesserimpact than the established trans-Atlantic core. ${ }^{34}$ In brief, we ask whether African agency can seize the opportunity to become the primary driver of regional development in the second half of the second decade of the 21st century. ${ }^{35}$

\section{AMV AS AFRICAN AGENCY}

The most dramatic example of African agency in the policy landscape to date is the articulation of theAMV at the turn of the decade, which is itself a synthesis of the ongoing redefinition of energy and resource governance in the emerging African developmental state. Agency has been reformulated in a variety of regions and sectors by Floriniand Dubash, Goldthauand Witte, ${ }^{36}$ and Kuzemko et al ${ }^{37}$ building on generic notions of transnational, private governance. ${ }^{38}$ AMV is in keeping with such reformulations, which is why it is advocated by Africa's interstate

33 ACBF, Africa Capacity Building Indicators: Capacity Development In Fragile States (Harare, 2011).

34 Pieterse Jan Nederveen, "Global rebalancing: crisis and the East-South turn", Development and Change (2011), Vol. 42(1), 22-48.

35 Harman, S. and David, W. (eds), Governing the World? Cases in Global Governance (Abingdon: Routledge, 2013).

36 Goldthau, A. and J. M. Witte (eds), Global Energy Governance: The New Rules of the Game (Washington: Brookings Institution, 2010).

37 Kuzemko, Caroline et al (eds), Dynamics of Energy Governance in Europe and Russia (London: Palgrave Macmillan 2012).

38 op. cit. 
agencies, and perceived as areflection of the continent's newfound resilience. The AMV faces serious competition from several other alternatives, including regional, global, unisectoral, multisectoral, unistakeholder, and multistakeholder.

The AMV was preceded at the start of the century by the Mining Policy Framework (MPF) of the Inter-Governmental Forum (IGF), which was to be joined by NRC in terms of resource governance, but challenged by a continuously-evolving EITI in terms of financial arrangements. Meanwhile, a US federal agency, the SEC, is imposing new norms and public rankings of corporate compliance in the information technology sector around conflict metals out of the Congoin association with the ICGLR. This is to better ensure that high-tech,multinational corporations act in keeping with the interests of a range of local to global, minor to major NGOs.

The EU seeks to follow suit by extending the reach of its supply chain accountability to forestry. The corporate sector's own agency, theInternational Council on Mining and Metals (ICMM), has generated its own rules for NRG, as have the World Economic Forum (WEF) and OECD.The ICMM adheres to the Resource Endowment Initiative, while the WEF follows the "Vision on Responsible Mineral Development". The OECD acts with respect to its Due Diligence Guidance for Responsive Supply Chain of Minerals from Conflict-Affected and High Risk Areas. The rules advocated by these organizationsare aimed at implementing sound operating principles based on collaboration with local stakeholders to ensure broadly beneficial NRG over the long term.

The AMV was developed towards the end of the first decade of the present century to advocate sustainable development towards industrialization. It is based on a comprehensive and informed report by an International Study Group on "Minerals and Africa's Development", ${ }^{39}$ which attempted to delineate the steps neededto effectively manage Africa's extractives sector.It focused on a mix of established and novel issues such as environmental concerns, artisanal and small-scale mining (ASM), CSR, maximization and management of revenues, research and development (R\&D), and sustainability via backward and forward linkages to make the best use ofextractives revenues.In so doing, the documentemphasizes the imperatives of good

39 AMV, "Minerals and Africa's Development: International Study Group Report on Africa's Mineral Regimes" (Addis Ababa, 2011a). 
governance and the importance of robust regionalisms, marking a departure from the other, earlier MPF and later Dodd-Frank forms of NRG, which impact the continent with a focus on regional cooperation, policy development, and Research and Development. ${ }^{40}$

Africa can build on the current trend towards dynamic and heterogeneous varieties of collaborative, transnational governanceby advancing a network or public fora for debate, rather than the traditional $c l u b$ forms of diplomacy involving civil society and private companies as well as states and intergovernmental agencies.Despite its proposed rebranding, the 21st century African developmental state nevertheless lacks the capacity to act alone.It needs capable partners if it is to be effective in the post-2015, symbolized by the SDGs.

This lack of effective partnership accounts for the limited implementation of the AMV to date, as key players within the mining industry and civil society organizations - both within and outside of Africa - have hitherto delivered a muted response to the initiative. Mining companies may be deterred from actively participating because implementation of the vision could require them to invest large sums in managing projects to preserve the environmental and social integrity of the regions in which they operate over many years. Civil society organizations, on the other hand, may have been dissuaded from becoming involved in AMV implementation because of its emphasis on facilitating economic production without having adequately accounted for local ecological considerations. Moreover, forms of evaluation to plot the progress of the AMV seem to be lacking thus far, as a variety of heterogeneous diplomacies may be required to advanceand sustain such NRG.The Intergovernmental Forum on Mining, Minerals, Metals and Sustainable Development (IGF), however, did consider a comparative analysis of its established MPF and AMV in late 2012.

As the earlybird of African mining regulations, the IGF, which started life as a Global Dialogue on Mining, Metals and Sustainable Development, just marked its first decade of existence. The IGF is the culmination of a Canadian and South African initiative arising from the Johannesburg summit on sustainable development in 2002, although it was only formally instituted in 2005 through a partnership with the UN Commission on Sustainable Development (UNCSD). 
Despite the fact that fewer than 50 per cent of its 43 member stateshail from Africa,it tracks the UNCSD timetable and treats a range of industry, social, environmental and related issues such as communities, artisanal and small-scale mining (CASM), EITI and KP. Meanwhile, an unlikely source of enlightened regulation - the US Congress via the US Securities and Exchange Commission (SEC) - has enacted the Dodd-Frank megabill. Section 1502 of the act addresses conflict minerals and ranks the supplychains of the MNCs that consume them.This empowers the OECD, ICGLR and NGOs to evaluate IT manufacturers on their use of African minerals. Moreover, in June 2013, the EU amended its Transparency and Accounting Directives to emulateSEC Rule 13(q) added by Section 1504 of Dodd-Frank. The amendments require EUcompanies with large undertakings in natural resource extraction or logging of primary forests to report payments they make to governments where they operate.

\section{VARIETIES OF “TRANSNATIONAL” GOVERNANCE}

In an era still characterized by a single superpower, the mix of fragile or failed states, ${ }^{41}$ proliferating global issues and mounting pressures for democratization, accountability, and sustainability have generated some innovative forms of transnational, as well as aprivate governance system around the continent.These were symbolized by theOttawa and Kimberley Processes, and are now augmented by the Forestry Certification Scheme (FCS) andMarine Certification Scheme (MCS). The FCS and MCS form part of theexpanding ISEALAlliance as well as the UN Reducing Emissions from Deforestation and Forest Degradation in Developing Countries (REDD) Programme. These are not yet authoritative, and their scope still fails to reach continuing scourges like small arms and light weapons (SALW) despite progresstowards achieving an arms trade treaty (ATT) mid-decade. Nevertheless, transnational and private mechanisms are transforming the African governance landscape. When combined with innovative sources of finance, they begin to impact the regional policy terrain. Such approaches have encouragedtraditional international law to recognize different

41 ACBF, "African Capacity Review: Capacity Building or Regional Integration in Africa" (Harare, 2014); Also see, Brock, Lothar, Hans-Henrik, H. Georg, S. and Michael, S., "Fragile States: Violence and the Failure of Intervention" (Cambridge: Polity, 2012). 
varieties of global governance (Cadman, 2011; Gale and Hayward, 2012). Transnational and private governance regimes also constitute the backdrop to the AMV and parallel initiatives around NRG in Africa and elsewhere, with KP being the organic predecessor of SEC rules in response to Dodd-Frank.

As noted previously, recent comprehensive innovations include the industry-supported FCS and parallel MCS, which serve ascornerstonesof the burgeoning ISEAL Alliance. ${ }^{42}$

Aside from AMV, the four compelling schemes in the African context are (i) the pioneering, decade-old IGF, which has now articulated an MPF; (ii) the international financial institution-endorsed NRC, which involvesanalysts and other specialists discussing desiderata for the sector; (iii) the G8-supported EITI, which is timely given the dangers posed by a resource curse; and (iv) the latest development, which is both unilateral and regional with global reach. It stands at the crossroads ofconflict mineral production in Africa's Great Lakes Region (GLR) and Section 1504 of the Dodd-Frank Act, which amended theSecurities Exchange Act through the addition of Section 13(q). Thisauthorizes the SEC to issue rules compelling entities engaged in the commercial development of oil, gas or other minerals to annually disclose the payments they have made to governments according totype and project. Given the salience of this US legislation, a veritable cottage industry has sprung up around it to advance compliance. ${ }^{43}$

These five transnational NRG networks (AMV, EITI, IGF, NRC and SEC) each entail different assumptions, emphases and preferences. For this reason, one must question whether the establishment of an agreeable, productive, and sustainable division of labouramong them is desirable, or even possible. In terms of geographic scope, the SEC is the most regional and focused in its objective, while the AMV is continental in outlook. The NRC appears to be the most global of the five. In relation to types of actors, the IGF is the most state-centric and green in orientation.It is followed in this respect by the AMV, which is driven by intergovernmental agencies; including some established OECD donors.

In terms of sectoral focus, the SEC concentrates on a limited range of high-tech minerals, while the EITI is preoccupied by financial

42 Available at <www.isealalliance.org > accessed March 2016.

43 See <http://dodd-frank.com; http://section1502.com> accessed March 2016. 
considerations. ${ }^{44}$ The NRC, is observably animated by academics mainly from the global North.Led by the likes of Zedillo and Ibrahim, the group's board hasidentified a dozen precepts that seek to bring about effective NRG. EITI seems to be the hegemonic entity with respect to managing corruption. EITI and NRC are the most endorsed by OECD donors, while AMV is least so.Some of the more mining focused countries within the G20 are most supportive of IGF, while the SEC is US-centric, whichhas implications for major IT corporations in Asia and elsewhere. As each of the five aforementioned governance mechanisms depend on coherence with financial policies at the global, regional and local levels, I turn next to burgeoning varieties of finance now available to Africa and the rest of the global South. These impact on the continent's response to alternative forms of NRG, as it is confronted with greater choice and they arereflective of Africa's growing agency.

\section{VARIETIES OF INNOVATIVE SOURCES OF FINANCE}

Even before the global financial crisis, there had been a substantial gap in funding for African development militating against the realization of the MDGs in 2015; hence the current preoccupation with post-2015 development directions. In response to such deficiencies,along with the slowness of the Monterrey Consensus to impact ODA effectiveness, from Accra and Paris to Busan at the end of 2011, France animated a leading group of states to suggest other means to advance global public goods. In association with major INGOs in theforum on the future of aid, a Taskforce on International Financial Transactions and Development came to advance the notion of taxation for the governing of globalization by 2020 .

Other alternatives included ODA from new members of the EU and the BRICS as emerging donors, ${ }^{45}$ with the latter reflected in the Forum on China-Africa Cooperation (FOCAC), for example. ${ }^{46} \mathrm{New}$ private foundations have emerged since the turn of the century to parallel

44 Campbell Bonnie (eds.), Modes of Governance \& Revenue Flows in African Mining (London: Palgrave Macmillan, 2013).

45 Sumner, A. and Tom K. (eds), "Donors' Dilemma” (London: Global Policy, 2014).

46 Taylor Ian C., "The Forum on China-Africa Cooperation (FOCAC)" (Abingdon: Routledge, 2011). 
established names, such as Carnegie, Ford, Rockefeller, and Gates.The Blair, Clinton and Ibrahim Foundations have accompanied these established entitiesin the post-2000 international development landscape (Besada and Kindornay, 2013). Similarly, FBOs increasingly span many religions, particularly the more pragmatic, mainstream denominations (e.g. Aga Khan Foundation (AKF), Catholic Relief Services (CRS), Islamic Relief, Lutheran World Relief (LWR) and World Vision). With new as well as established private foundations, they increasingly partner with international organizations such asthe Alliance for a Green Revolution in Africa (AGRA) and Global Alliance for Vaccines and Immunization (GAVI) (Rushton and Williams 2011). Among the dozen or so global levies, mainly on ubiquitous financial flows, proposed by the Taskforce to advance global public goods were:

i. Global Solidarity Fund (GSF) for global public goods;

ii. Currency Transaction Tax (CTT), along the lines of the original Tobin Tax in the EU;

iii. An airline ticket levy already being implemented by some governments in the global North like France and Korea, with revenues going for anti-AIDS, tuberculosis and malaria (ATM) vaccines in association with the Clinton and Gates Foundations;

iv. Carbon taxes/trading, witha controversial set of measures encouraged by the UN Inter-governmental Panel on Climate Change (IPCC) and a set of climate change summits, such as the landmarkCOP21 in Paris;

v. Climate change funds, such as the International Bank for Reconstruction and Development's Global Environmental Facility (GEF) and UN agencies' Reducing Emissions from Deforestation and Forest Degradation in Developing Countries (REDD);

vi. Digital Solidarity Fund (DSF) established in Geneva;

vii. UNITAID, an international drug purchase facility to advance access to ATMs, now with broad inter- and non-state participation;

viii. Controls on money-laundering encouraged by the OECD and G8, including capital flight per annum, estimated to amount to some US\$500 billionmid-decade.Other institutions facilitating money laundering controls include the global and Caribbean Financial Action Task Forces (FATF/CFATF) on off- 
shore financial centres (OFCs) over two decades; leading to Publish What You Pay (PWYP) and EITI; and

ix. Remittance taxes on capital flows between the global North and global South; which have burgeoned to over US $\$ 300$ billion pa (Ratha, 2011; World Bank, 2011). Remittance tax income now constitutes a greater revenue stream for Nigeria and Lesotho than ODA.

Getting from conceptualization to policies and politics is problematic as capacity is limited.This is where varieties of regionalisms become relevant inengaging the public in open diplomacy. ${ }^{47}$ This supports the imperative toenter into a timely, extensive coalition to redefine and revive Africa's direction.

\section{VARIETIES OF NEW REGIONALISMS}

Reflective of the constraints on many of its more than 50 states, Africa has been the leading region in the South to advance regional innovations and institutions, even if it has received less analytic attention thanAsia. In the initial, one-party nationalist period, reflective of jealousy surrounding newly realized independence, these were typically "old" inter-governmental arrangements. In the post-bipolar era, however, such regionalisms became less exclusively state and economic oriented, and more inclusive around emerging issues like ecology, energy, security, and water. ${ }^{48}$ Regional development is now increasingly focused on new infrastructures, such as corridors for supplies (SID 2012) and pipelines and valleys for energy and water (Fanta, Shaw and Tang 2013), symbolized by the new eastern Africa as a rising energy region (The Economist 2012). Hence the relevance of Trade Mark in Southern and East Africa (TMSA and TMEA), which is facilitating regional infrastructures, networks and supply-chains (SID 2012). ${ }^{49}$

First, the revived, redefined East African Community is emblematic of "new" African regionalisms, now consisting ofsix rather than the

47 Fanta, Emmanuel, Timothy, M. S. and Vanessa, T. (eds), Comparative Regionalisms for Development in the 21st Century: Insights from the Global South (Farnham: Ashgate for NETRIS, 2013).

48 ibid 2011.

49 Available at <www.trademarkea.com, www.trademarksa.org > accessed August 2016. 
initial three members (Hansohm, 2013). The organization is characterized byinnovative civil society, media, parliamentary and security dimensions (SID 2012), and qualifies as an instance of "new regionalisms" (Shaw, Grant and Cornelissen, 2011). Given the scale and resilience that has been demonstrated in managing regional conflicts on the continent in recent years, several attempts have been made at regional peace-building, from Darfur to Cote d'Ivoire, especially through ECOWAS, GLR, Horn and so on.

The ongoing process surrounding the International Conference on the Great Lakes Region serves as one such example; being reinforced and publicized by SEC Section 1502 on conflict metals. These increasingly involve a fluid range of actors in a heterogeneous coalition (Leonard 2013), from INGOs to MNCs.As conflicts are always about greed as well as grief, resource extraction and accumulation proceeding in tandem with violence all too often target women and children, as successive UN reports on the Congo have revealed. Moreover, as security is increasingly privatized, such coalitions become ever more problematic. This is particularly so around energy and mineral extraction and supply-chains, as their products attract the attention of transnational as well as local criminal networks. Shorter-term peacemaking is typically tied to longer-term norm-creation to advance sustainable development by regulating the flow of $3 \mathrm{~T}$ conflict metals and minerals like coltan, diamonds and gold, as previously indicated. ${ }^{50}$

Second, in the new century, African regionalisms have come to encompass micro, meso, and macro levels and sectors; includingcivil society organizations, corporate networks, and security apparatus. ${ }^{51}$ While Export-Processing Zones (EPZs) are associated with Asia, and gas pipelines with Central Europe, development corridors and peaceparks are largely a function of Southern Africa's distinctive political economy. ${ }^{52}$ Similarly, Africa has its share of river valley organizations (e.g. Congo, Niger, Nile, Zambezi) and other cross-border, micro-regions. The Maputo Corridor has advanced growth in Southern Mozambique, as well as the eastern Witwatersrand, reinforcing the cross-border

50 Available at www.enoughproject.org, accessed August 2016.

51 Soderbaum, F. and Ian, T. (eds), "Afro-Regions: The Dynamics of Cross-Border Macro-Regionalism in Africa" (Uppsala: NAI, 2008).

52 RamutsindelaMaano, "Transfrontier Conservation and the Spaces of Regionalisms" in Shaw, Grant and Cornelissen (eds), "The Ashgate Research Companion to Regionalisms" (2011), 361-373. 
dimensions of the Lesotho highlands water project for electricity and water; the latter was informed by the only global commission to be based outside the North (in Cape Town, South Africa) which also included MNCs as well as NGOs and states in its membership: the World Commission on Dams. Reflective of growing concern for the environment, Southern Africa is the centre of the trans-frontier peaceparks movement, which has led to the recognition of several such crossborder parks in the region. These may evolve from designated elephant corridors into multipurpose functional arrangements for renewable energy and water resources.

Third, encouraged by the growing recognition of climate change, the development of IBSA into BASIC around COP15 in Copenhagen at end-2009 and beyond to Paris end-2015, the continent's river basins are beginning to receive considerable attention as centres of biodiversity, energy, food and water, as well as conflict. The Nile Basin Initiative and Dialogue arearguably the most advanced to date.

Fourth, symptomatic of emerging tensions and possibilities is the discovery of oil around the rift valley lakes in northwest Uganda, along the border with Congo.Such oil production may propel Uganda into the ranks of the developmental states, but could endanger some of its environment, wildlife, and local communities in the process. In early 2012, new discoveries of oil and gas were announced in northern Kenya, southern Ethiopia, northern Mozambique, and southern Tanzania by a series of global energy players, ${ }^{53}$ an emerging energy exporting region of growing importance for AMV. The first East Africa Oil and Gas Summit was held in Nairobi in November 2012 to discuss pipelines from Juba to Lamu, and from Mtwara to Dar and Mombasa.The summit also addressed the establishment of an oil refinery in northern Uganda. Some of the fifty global energy companies involved in this new Eastern Africa include China's CNPC and CNOOC, US Anardarko, ExxonMobil and BG, ENI, Statoil and Tullow from Europe.

Fifth, the continent's pattern of inter-regional relationships is in flux, moving frominherited North-South dependencies towards a novel South-East axis involving China, India, Japan, and Korea. Symbolically, reluctance on the part of African regions to sign Economic Partnership Agreements (EPAs) with the EU at the turn of the decade - despite being confronted by a mixture of pressures and incentives- may mark

53 Economist, “African Energy: eastern el dorado?" (2012). 
a turning point as global rebalancing continues. ${ }^{54}$ Europe continues to contend with the Eurozone crisis centred around the PIIGS countries, while Asia is steadily being transformed by BRICS strategy making and policy formulations for the continent. ${ }^{55}$ These developments advance the prospects for African agency. The tone of annual African-China FOCAC discussions can be contrasted with the tenor of the third EUAfrica summit held in Tunis in November 2010. Symptomatically, Iberia increasingly relies on investment from and emigration to Angola, Brazil, Mexico and Mozambique rather than vice versa.

Finally, given its numerous land-locked states, Africa has always experienced informal cross-border migration and trade.Some of these economic activitiesnow includeillegal goods like drugs and small arms. ${ }^{56}$ As MNCs, from China and India as well as South Africa (hence the transition from IBSA to BRICS) have increased their investments in energy and minerals, franchises and shopping malls throughout the continent, so their logistics and supply chains have come to define their own regional networks. ${ }^{57}$ Exponential infrastructural development will further new regionalisms on the continent in the second decade of the 21st century; symbolized by the mobile phone revolution and the roles of MTN, Bharti Airtel, and the Mo Ibrahim Foundation. I conclude thusby posing questions about the implications of developments in $\mathrm{NRG}$, finance and regionalisms for African policy making in the post2015 environment.

\section{INNOVATIVE POLICIES}

Burgeoning varieties of NRG, finance, and regionalisms are reinforcing prospects for public policy development in Africa. They also present the continent with challenges that "innovative" state and non-state policies and perspectives be advanced by a variety of actors (i.e. by local to global civil society organizations, private companies, media, and so on).

54 Fawn Rick (eds.), "Special Issue: Globalizing the Regional, Regionalizing the Global", Review of International Studies (2009), Vol. 35, 1-261.

55 Cheru, F. and Cyril, O. (eds), The Rise of China and India in Africa (London: Zed for NAI 2010).

56 Available at <www.wacommissionondrugs.oeg > accessed July 2016.

57 Power, Marcus, Giles, M. and May, T. M., China's Resource Diplomacy in Africa: Powering Development? (London: Palgrave Macmillan, 2012). 
Africa is currently at the crossroads in terms of development governance, ${ }^{58}$ symbolized by the Africa Mining Vision (AMV) and the ambition to become developmental states. Will the continent be able to transcend its somewhat lacklustre first half-century and realize significant, sustainable economic development over the next fifty years? Can African interests advance the inclusive public or network diplomacy of state and non-state actors for the most marginalized continent in the global South using new media and technologies, as suggested in the transition from KP to ICGLR? Africa's place at the centre of innovative sources of finance and governance systemsprovides us with cause for optimism, ${ }^{59}$ while the number of ongoing conflicts and persistently fragile and failed states on the continentfuelsscepticismand pessimism (Brock, Holm Sorensen and Stohl 2012). In Africa, as elsewhere in the global South, what balance can be struck between regional conflict and regional development? As Brown succinctly states:

... future work on African agency would be able to engage seriously with the continent's role in international politics in a way that presents Africa as actor and not just acted upon, historical agent not just history's recipient.

Africa'soptions rely on some of the explicit or implicit policy directions proposed in this and other essays advancing beyond 2015 in a logical, cumulative sequence, for state and non-state, intra- and extra-African actors alike, while focusing on accountable, sustainable, and transparent regulation for development rooted in the AMV, but augmented by EITI. First, given its indigenous roots and compatibility with the push for developmental states, AMV should take precedence while being reinforced by Dodd-Frank (and its EU counterpart: Transparency and Accountability Directives), MPF, and NRC. Second, EITI should maximize transparency and minimize leakages to OFCs. Third, SWFs should be encouraged, as in Botswana, Albertaand Norway, to reduce the risks of the resource curse and inflation. Fourth, the new Eastern African energy region should be developed via appropriate infrastructure and technologies, and by learning from the difficulties or mistakes previously encountered in Africa. Agency implies African ownership, otherwise the promise of a renaissance will prove illusory.

58 Available at <www.africaprogresspanel.org > accessed August 2016.

59 UNECA, "African Governance Report II" (Addis Ababa, 2009). 
Moreover, African states can demand that laggard governments such as Canada's catch up with the EU, US and others in the OECD in terms of CSR around NRG, including going beyond KP towards an attainment of the objectives set out in Dodd-Frank. 